\title{
Analisis Dampak Kebijakan E-Catalogue terhadap Profil Pengadaan Obat di Instalasi Farmasi RSUP Fatmawati
}

\section{Analysis of the Impact of E-Catalogue Policy on Drug Procurement Profile in the Pharmacy Department of Fatmawati Central General Hospital}

\author{
Setyawati Permata ${ }^{1 *}$, Yusi Anggriani ${ }^{1}$, Maria Sukmawati Lesilolo ${ }^{2}$ \\ ${ }^{1}$ Faculty of Pharmacy, Pancasila University, \\ Jl.Srengseng Sawah, Jagakarsa, Jakarta Selatan, Jakarta 12640, Indonesia \\ ${ }^{2}$ Fatmawati Central General Hospital, \\ Jl. TB Simatupang No. 18, Cilandak, Jakarta Selatan, Jakarta 12430, Indonesia \\ *Corresponding author email: setyawati.permata@gmail.com
}

Received 01-07-2019 Accepted 17-02-2020 Available online 01-07-2020

\begin{abstract}
ABSTRAK
Pemerintah Indonesia mengendalikan harga secara langsung melalui LKPP (Lembaga Kebijakan Pengadaan Barang/Jasa Pemerintah) dengan menetapkan harga e-catalogue untuk pengadaan obat bagi pasien yang menggunakan sistem pembiayaan JKN-BPJS (Jaminan Kesehatan Nasional-Badan Penyelenggara Jaminan Sosial). Penelitian ini bertujuan untuk mengetahui dampak kebijakan e-catalogue pada profil pengadaan obat di Instalasi Farmasi Rumah Sakit Umum Fatmawati, baik yang ada dalam daftar $e$ catalogue dan non e-catalogue. Penelitian ini menggunakan desain penelitian observasional, analitik kuantitatif dengan longitudinal time series. Pengumpulan data dilakukan secara retrospektif menggunakan data harga pengadaan obat dari Sistem Informasi Rumah Sakit pada periode Januari 2011-Desember 2016. Hasil penelitian pada profil pengadaan obat menunjukkan persentase pengadaan obat e-catalogue, setelah penerapan e-catalogue $(20,0-29,4 \%)$ lebih tinggi dari sebelumnya $(10,0-17,2 \%)$, dan obat non e-catalogue lebih rendah setelah penerapan e-catalogue $(70,6-80,0 \%)$ dari sebelumnya $(82,8-90,0 \%)$. Persentase pengadaan obat setelah penerapan e-catalogue berdasarkan jenisnya: obat e-catalogue generik lebih tinggi $(4,5-8,0 \%)$ dibandingkan sebelumnya $(1,2-4,4 \%)$, obat generik non e-catalogue lebih tinggi $(12,7-16,2 \%)$ daripada sebelumnya (4,4-14,1\%), obat dengan nama dagang e-catalogue lebih tinggi (12,3$17,8 \%)$ daripada sebelumnya $(5,6-12,4 \%)$, obat dengan nama dagang non e-catalogue lebih rendah $(53,1-65,7 \%)$ dari sebelumnya $(67,4-79,9 \%)$, obat paten e-catalogue lebih tinggi $(2,7-4,2 \%)$ dari sebelumnya $(1,8-3,6 \%)$, obat paten non e-catalogue hampir sama $(1,4-1,9 \%)$ dari sebelumnya (1,1-1,9\%). Kesimpulan dari studi ini adalah kebijakan $e$ catalogue meningkatkan pengadaan obat, baik obat generik, obat nama dagang, maupun obat paten yang ada dalam daftar e-catalogue.
\end{abstract}

Kata kunci: e-catalogue, obat generik, obat nama dagang, obat paten. 


\begin{abstract}
The Indonesia government controls prices directly through LKPP (National Public Procurement Agency) by setting e-catalogue prices for drug procurement for patients using the JKN-BPJS (National Health Insurance-Social Security Administrative Body) financing system. This study aimed to determine the impact of e-catalogue policy on drug procurement profile in the Pharmacy Department of Fatmawati Central General Hospital, both in the e-catalogue and non-e-catalogue lists. The study used an observational study design, with quantitative analytic by longitudinal time series. Data collection was conducted retrospectively using data on drug procurement prices from the Hospital Information System from January 2011 to December 2016. The results of the profile of drug procurement study showed the percentage of e-catalogue drug procurement after the implementation of e-catalogue (20.0-29.4\%) was higher than before (10.0-17.2\%), while that in non-e-catalogue drugs was lower after the implementation of e-catalogue (70.6-80.0\%) than before (82.8-90.0\%). Percentage of drug procurement after implementation of the policy on each type was as follow: generic (International Nonproprietary Names/INN) e-catalogue drugs were higher (4.5-8.0\%) than before (1.2-4.4\%), non-e-catalog generic drugs were higher (12.7-16.2\%) than before (4.4-14.1\%), drugs in the e-catalogue brand name were higher (12.3-17.8\%) than before (5.6-12.4\%), non-e-catalogue brand name drugs were lower (53.1-65.7\%) than before (67.4-79.9\%), patent drugs e-catalogue was higher (2.7-4.2\%) than before (1.8$3.6 \%)$, non-e-catalogue patent drugs were almost the same (1.4-1.9\%) than before (1,11.9\%). The conclusion of this study is the e-catalogue policy has increased procurement of generic, brand name, and patent drugs in the e-catalogue list.
\end{abstract}

Key words: brand name drug, e-catalogue, INN drugs, patent drugs.

\section{Pendahuluan}

Keterjangkauan

sistem

kesehatan tergantung pada harga obat berikut anggaran sistem kesehatan dalam pembelanjaan obat. Indikator yang umum digunakan dalam mengukur pembiayaan sistem kesehatan di bidang obat antara lain proporsi dari total belanja kesehatan untuk obat, jumlah pembelanjaan farmasi sebagai persentase dari PDB (Produk Domestik Bruto), dan pembelanjaan farmasi per kapita (Lu et al., 2011).

Pada semua sektor pelayanan kesehatan publik menggambarkan bahwa pasien sering membayar harga obat generik tanpa merek melebihi harga eceran maksimum yang ditetapkan oleh Kementerian Kesehatan. Di sektor publik, perbedaan antara harga rata-rata dan harga eceran maksimum berkisar antara 5 sampai 202\%. Di sektor swasta, beda antara harga median dan harga eceran maksimum sekitar 9 sampai $661 \%$. Jumlah obat tertinggi yang melebihi harga eceran maksimum ditemukan di sektor swasta (Anggriani et al., 2013).

Salah satu metode utama pengaturan harga obat adalah dengan harga referensi eksternal dan harga referensi internal. Harga referensi 
eksternal (perbandingan harga Internasional) menggunakan harga produk obat di satu atau beberapa negara untuk memperoleh patokan dengan tujuan pengaturan atau negosiasi harga produk yang ditetapkan oleh negara. Harga referensi internal biasanya digunakan untuk meregulasi harga obat yang habis masa patennya. Hal ini dilaksanakan dengan mengatur harga yang dibayar oleh pasien umum dengan membandingkan harga produk yang setara secara kimia, farmakologis atau kelompok terapetik (Ruggeri dan Nolte, 2013).

Di beberapa negara, sistem pengaturan harga dibagi menjadi 3 metode, yaitu:

1. Harga Gratis, misalnya di negaranegara Jerman, Belanda, Denmark.

2. Kontrol Harga Langsung, misalnya di negara-negara Prancis, Italia, Portugal, Yunani, Spanyol, Turki, Belgia.

3. Kontrol Margin, misalnya di negara Inggris (Atikeler dan Ozcelikayz, 2016).

Di Indonesia, pemerintah melakukan kontrol harga langsung melalui LKPP dengan menetapkan harga e-catalogue untuk pengadaan obat bagi pasien yang menggunakan sistem pembiayaan JKN-BPJS. Pengelolaan obat bertujuan terjaminnya ketersediaan obat yang bermutu baik, secara tepat jenis, tepat jumlah, tepat waktu, serta digunakan secara rasional, sehingga dana yang tersedia dapat digunakan dengan sebaik-baiknya dan berkesinambungan guna memenuhi kepentingan masyarakat yang berobat ke unit pelayanan kesehatan dasar (Oktaviani dan Baroroh, 2015).

Pengelolaan obat tersebut dapat menghemat biaya penyelenggaraan perbekalan obat sampai $10 \%$ dan biaya operasional pengelolaan rantai suplai obat di rumah sakit bisa mencapai $40 \%$. Untuk mencapai penghematan harga yang berimbas pada adanya penurunan harga obat, maka pemerintah juga ikut mengambil peran, yaitu dengan memberlakukan sistem JKN dan membagi obat-obatan tersebut menjadi 2 kategori, yaitu obat e-catalogue dan non e-catalogue (Darling dan Wise, 2010; Susanto et al., 2017). Berdasarkan hal tersebut, maka penelitian ini dilakukan dengan tujuan untuk mengetahui dampak penerapan kebijakan e-catalogue pada profil pengadaan obat di Instalasi Farmasi Rumah Sakit Umum Fatmawati, baik yang ada dalam daftar e-catalogue dan non e-catalogue.

\section{Metode Penelitian}

Penelitian ini menggunakan desain studi observasional, analitik kuantitatif dengan longitudinal time series. Pengumpulan data dilakukan secara retrospektif menggunakan data harga pengadaan obat dari Sistem Informasi Rumah Sakit pada periode Januari 2011-Desember 2016. Penelitian dilakukan terhadap harga obat generik, obat dengan nama dagang, maupun obat paten yang ada di dalam daftar $e$ catalogue ataupun non e-catalogue yang diadakan oleh Instalasi Farmasi RSUP 
Fatmawati selama kurun waktu 20112016.

\section{Hasil dan Pembahasan}

Perbandingan Pengadaan Obat eCatalogue dan non e-Catalogue

Hasil penelitian terhadap nama dan harga obat menunjukkan sejumlah 1862 item obat pada awal periode yaitu semester I tahun 2011, sampai semester II tahun 2016 sejumlah 1013 item obat. Jumlah item dan persentase pengadaan obat di Instalasi Farmasi RSUP Fatmawati yang diamati terbagi dalam 2 periode, yaitu sebelum pelaksanaan penerapan kebijakan e-catalogue, pada periode tahun 2011-2013 dan setelah penerapan kebijakan e-catalogue, pada periode tahun 2014-2016. Pada masing-masing tahun, dibagi menjadi 2 semester, yaitu semester pertama dan semester kedua.

Kelompok obat yang diadakan kemudian dibagi menjadi 2 kelompok besar, yaitu kelompok obat e-catalogue dan kelompok obat non e-catalogue. Pada masing-masing kelompok, dibagi lagi berdasarkan jenis obat, yaitu generik, nama dagang, dan paten. Data yang dihasilkan ditunjukkan pada Tabel 1 dan Tabel 2.

Tabel 1. Jumlah dan persentase pengadaan obat e-catalogue di RSUP Fatmawati tahun 2011-2016

\begin{tabular}{|c|c|c|c|c|c|c|c|c|c|}
\hline \multirow{3}{*}{ No } & \multirow{3}{*}{$\begin{array}{l}\text { Periode } \\
\text { Pembelian }\end{array}$} & \multicolumn{8}{|c|}{ e-Catalogue } \\
\hline & & \multicolumn{2}{|c|}{ Generik } & \multicolumn{2}{|c|}{ Nama Dagang } & \multicolumn{2}{|c|}{ Paten } & \multicolumn{2}{|c|}{ Jumlah } \\
\hline & & $\mathbf{N}$ & $\%$ & $\mathbf{N}$ & $\%$ & $\mathbf{N}$ & $\%$ & $\mathbf{N}$ & $\%$ \\
\hline 1 & 2011.a & 49 & 2,6 & 104 & 5,6 & 34 & 1,8 & 187 & 10,0 \\
\hline 2 & 2011.b & 51 & 3,3 & 122 & 8,0 & 29 & 1,9 & 202 & 13,2 \\
\hline 3 & 2012.a & 8 & 1,2 & 84 & 2,4 & 24 & 3,6 & 116 & 17,2 \\
\hline 4 & 2012.b & 35 & 2,5 & 139 & 0,1 & 28 & 2,0 & 202 & 14,7 \\
\hline 5 & 2013.a & 46 & 3,3 & 151 & 0.8 & 37 & 2,7 & 234 & 16,8 \\
\hline 6 & 2013.b & 31 & 2,6 & 133 & 1,3 & 34 & 2,9 & 198 & 16,8 \\
\hline 7 & 2014.a & 66 & 5,1 & 160 & 2,3 & 35 & 2,7 & 261 & 20,0 \\
\hline 8 & 2014.b & 57 & 4,5 & 164 & 2,8 & 36 & 2,8 & 257 & 20,1 \\
\hline 9 & 2015.a & 75 & 7,8 & 160 & 6,6 & 36 & 3,7 & 271 & 28,2 \\
\hline 10 & 2015.b & 67 & 7,1 & 161 & 7,1 & 40 & 4,2 & 268 & 28,4 \\
\hline 11 & 2016.a & 68 & 6,7 & 174 & 7,1 & 38 & 3,7 & 280 & 27,5 \\
\hline 12 & 2016.b & 81 & 8,0 & 180 & 7,8 & 37 & 3,7 & 298 & 29,4 \\
\hline
\end{tabular}

Tabel 1 menunjukkan persentase pengadaan obat $e$-catalogue lebih tinggi pada periode setelah penerapan kebijakan e-catalogue pada tahun 2014, yaitu pada kisaran 20,0-29,4\% pada semester I tahun 2014 sampai semester II tahun 2016 dibandingkan pada periode sebelum pemberlakuan kebijakan $e$ catalogue. Persentase pengadaan obat e-catalogue berada pada kisaran 10,0 sampai $17,2 \%$ pada periode semester I tahun 2011 sampai semester II tahun 2013. Tabel 2 memperlihatkan persentase pengadaan obat non $e$ - 
catalogue lebih rendah pada semester I tahun 2014 sampai semester II tahun 2016 pada kisaran 70,6-80,0\% dibandingkan dengan periode sebelum penerapan kebijakan e-catalogue, semester I tahun 2011 sampai semester II tahun 2013 yang berada pada kisaran angka 82,8 sampai $90,0 \%$.

Tabel 2. Jumlah dan persentase pengadaan obat non e-catalogue di RSUP Fatmawati tahun 2011-2016

\begin{tabular}{|c|c|c|c|c|c|c|c|c|c|}
\hline \multirow{3}{*}{ No } & \multirow{3}{*}{$\begin{array}{l}\text { Periode } \\
\text { Pembelian }\end{array}$} & \multicolumn{8}{|c|}{ e-Catalogue } \\
\hline & & \multicolumn{2}{|c|}{ Generik } & \multicolumn{2}{|c|}{ Nama Dagang } & \multicolumn{2}{|c|}{ Paten } & \multicolumn{2}{|c|}{ Jumlah } \\
\hline & & $\mathbf{N}$ & $\%$ & $\mathbf{N}$ & $\%$ & $\mathbf{N}$ & $\%$ & $\mathbf{N}$ & $\%$ \\
\hline 1 & 2011.a & 168 & 9,0 & 1487 & 79,9 & 20 & 1,1 & 1675 & 90,0 \\
\hline 2 & 2011.b & 162 & 10,6 & 1144 & 74,9 & 19 & 1,2 & 1325 & 86,8 \\
\hline 3 & 2012.a & 30 & 4,4 & 520 & 76,9 & 10 & 1,5 & 560 & 82,8 \\
\hline 4 & 2012.b & 172 & 12,5 & 979 & 71,3 & 20 & 1,5 & 1171 & 85,3 \\
\hline 5 & 2013.a & 197 & 14,1 & 940 & 67,4 & 23 & 1,6 & 1160 & 83,2 \\
\hline 6 & 2013.b & 151 & 12,8 & 810 & 68,6 & 22 & 1,9 & 983 & 83,2 \\
\hline 7 & 2014.a & 167 & 12,8 & 858 & 65,7 & 19 & 1,5 & 1044 & 80,0 \\
\hline 8 & 2014.b & 163 & 12,7 & 839 & 65,5 & 21 & 1,6 & 1023 & 79,9 \\
\hline 9 & 2015.a & 147 & 15,3 & 531 & 55,2 & 13 & 1,4 & 691 & 71,8 \\
\hline 10 & 2015.b & 146 & 15,5 & 513 & 54,4 & 16 & 1,7 & 675 & 71,6 \\
\hline 11 & 2016.a & 165 & 16,2 & 556 & 54,7 & 16 & 1,6 & 737 & 72,5 \\
\hline 12 & 2016.b & 158 & 15,6 & 538 & 53,1 & 19 & 1,9 & 715 & 70,6 \\
\hline
\end{tabular}

Tabel 1 dan 2 menunjukkan bahwa kebijakan e-catalogue secara keseluruhan meningkatkan jumlah pengadaan obat yang berada dalam kontrol pemerintah, yaitu obat yang ada dalam daftar e-catalogue dan sebaliknya menekan jumlah pengadaan obat di luar kontrol pemerintah, yaitu obat non $e$ catalogue.

Penggunaan obat yang sesuai dengan e-catalogue meningkat pada periode setelah penerapan kebijakan $e$ catalogue, akan tetapi persentase pengadaan obat e-catalogue masih rendah, yaitu kurang dari $70 \%$. Hal ini disebabkan karena ketidaksesuaian Fornas (Formularium Nasional) dan $e$ catalogue. Fornas disusun dalam rangka untuk kendali mutu sedangkan $e$ catalogue dibuat dalam rangka kendali biaya. Akan tetapi di lapangan ternyata tidak semua obat Fornas tayang di $e$ catalogue. Dan sebaliknya, terdapat juga obat yang tidak masuk Fornas tetapi tayang di e-catalogue. Kondisi ini mengakibatkan terdapat obat yang tidak memiliki acuan harga sebagai dasar BPJS Kesehatan membayar klaim. Selanjutnya juga menimbulkan kesulitan bagi Faskes (Fasilitas Kesehatan) untuk melakukan pengadaan obat karena tidak semua obat yang dibutuhkan tersedia. Faktor penyebab lain adalah mekanisme pengadaan obat melalui e-catalogue yang belum optimal. Keterlambatan dan kegagalan lelang obat oleh LKPP masih 
terjadi, yang mengakibatkan e-catalogue baru dapat diakses pada bulan April tahun anggaran, misalnya untuk tahun 2016, e-catalogue baru dapat diakses pada bulan April 2016 (Ariati, 2017).

Pengadaan Obat Generik e-Catalogue dan Non e-Catalogue Periode 2011-2016

Gambar 1 menunjukkan bahwa persentase pengadaan obat generik $e$ catalogue setelah penerapan kebijakan e-catalogue pada semester I tahun 2014, terdapat kecenderungan lebih meningkat dibandingkan dengan sebelum penerapan kebijakan $e$ catalogue, yaitu pada kisaran 4,5-8,0\% dibandingkan dengan sebelum penerapan e-catalogue, yaitu 1,2-4,4\%. Persentase pengadaan obat generik non e-catalogue juga mengalami kecenderungan lebih tinggi pada periode setelah penerapan kebijakan $e$ catalogue, yaitu pada kisaran 12,7-16,2\% dibandingkan pada periode sebelum penerapan e-catalogue, yaitu antara 4,4$14,1 \%$.

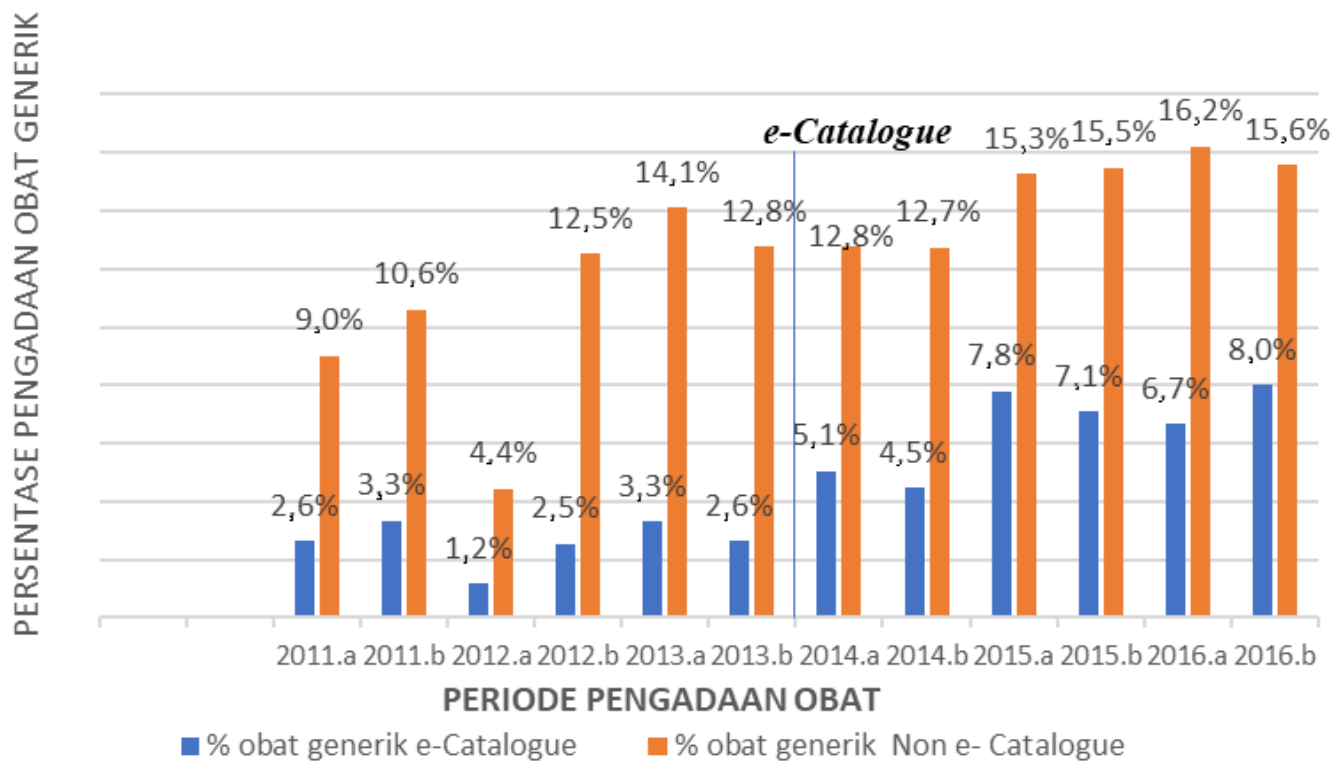

Gambar 1. Persentase pengadaan obat generik e-catalogue dan non e-catalogue periode tahun 2011-2016.

Peningkatan persentase pengadaan obat generik baik $e$ catalogue maupun non e-catalogue setelah era JKN, pada tahun 2016, masih belum seperti yang diharapkan, yaitu $23,6 \%$ dari keseluruhan jumlah pengadaan obat di Instalasi Farmasi
RSUP Fatmawati. Faktor-faktor yang menyebabkan hal ini terjadi adalah terkait dengan penulisan resep, sistem pasokan atau supply, dan manajemen persediaan obat generik, yang dapat menjadi titik kritis situasi ini, yaitu: 
1. Dari sudut pandang permintaan atau demand

Perlu edukasi bagi pasien mengenai obat generik. Kepercayaan masyarakat terhadap obat generik masih beragam dan salah satu faktor penyebabnya adalah persepsi tentang kualitas obat generik yang lebih rendah dibanding obat bermerek (Dewi, 2014). Pasien dapat mempengaruhi penulisan resep dokter (Fitriani et al., 2014). Dalam hal ini, diperlukan edukasi kepada pasien, bahwa meskipun harganya jauh lebih murah, sebenarnya tidak ada perbedaan kualitas obat antara kualitas obat generik jika dibandingkan dengan obat bermerek, karena obat generik dan obat bermerek sebenarnya merupakan obat copy dari obat paten (originator), sehingga tidak berbeda dalam hal zat aktif, indikasi, dan bentuk sediaan (Dewi, 2014).

2. Keputusan dokter dalam menuliskan resep

Keputusan dokter untuk menuliskan resep dipengaruhi pendidikan, informasi yang diterima dari sejawat, lingkungan tempat kerja dan industri farmasi, serta interaksi dengan pasien (Fitriani et al., 2014). Edukasi terhadap dokter juga penting mengingat kurangnya pendidikan yang berkelanjutan (continuing education) dan keahlian untuk mendapatkan informasi baru, sehingga informasi yang lebih banyak didapat dari pihak pemasaran obat, bukan berdasarkan evidence based medicine yang dapat mempengaruhi penulisan resep obat.

3. Sistem pasokan atau supply

Karena terdapat dugaan bahwa penerapan JKN membuat target pasar obat meningkat beberapa kali lipat untuk memenuhi kebutuhan 240 juta penduduk Indonesia. Artinya, peningkatan produksi obat khususnya obat generik juga perlu dilakukan oleh industri farmasi di Indonesia. Keputusan untuk meningkatkan produksi bergantung masing-masing industri farmasi dimana di dalamnya terdapat kemungkinan timbulnya hambatan masalah penjadwalan produksi dan ketersediaan bahan baku (Dewi, 2014).

4. Manajemen persediaan obat generik Manajemen persediaan obat dilihat dari pengelolaan stok, pengelolaan inventori, pengelolaan administratif, dan sistem informasi manajemen obat. Pemantauan penggunaan obat meliputi ketaatan terhadap pedoman pengobatan, formularium, dan peresepan generik (dalam era JKN obat generik diharapkan dapat diterapkan dengan baik), evaluasi penggunaan obat dan feedback, analisis terhadap data penggunaan obat, monitoring kesalahan pengobatan, monitoring mutu obat, serta pendidikan berkelanjutan yang bebas pesan sponsor. Sponsor harus melalui institusi, tidak boleh langsung ke pribadi, supaya tidak terpacu untuk menggunakan obat tertentu karena 
ada faktor balas budi (Prabowo et al., 2016).

Pengadaan Obat Nama Dagang eCatalogue dan Non e-Catalogue Periode 2011-2016

Gambar 2 memperlihatkan persentase pengadaan obat e-catalogue dengan nama dagang pada periode setelah penerapan kebijakan $e$ catalogue, semester I tahun 2014. Terdapat kecenderungan lebih tinggi, pada kisaran angka 12,3-17,8\% dibandingkan dengan sebelum penerapan kebijakan e-catalogue yang berada pada kisaran angka 5,6-12,4\%. Persentase pengadaan jenis obat nama dagang non e-catalogue pada periode setelah penerapan kebijakan e-catalogue semester I tahun 2014 menunjukkan kecenderungan lebih rendah dibandingkan sebelum penerapan kebijakan e-catalogue yaitu pada kisaran angka 53,1-65,7\% dibandingkan periode sebelumnya, yaitu pada kisaran angka $67,4-79,9 \%$.

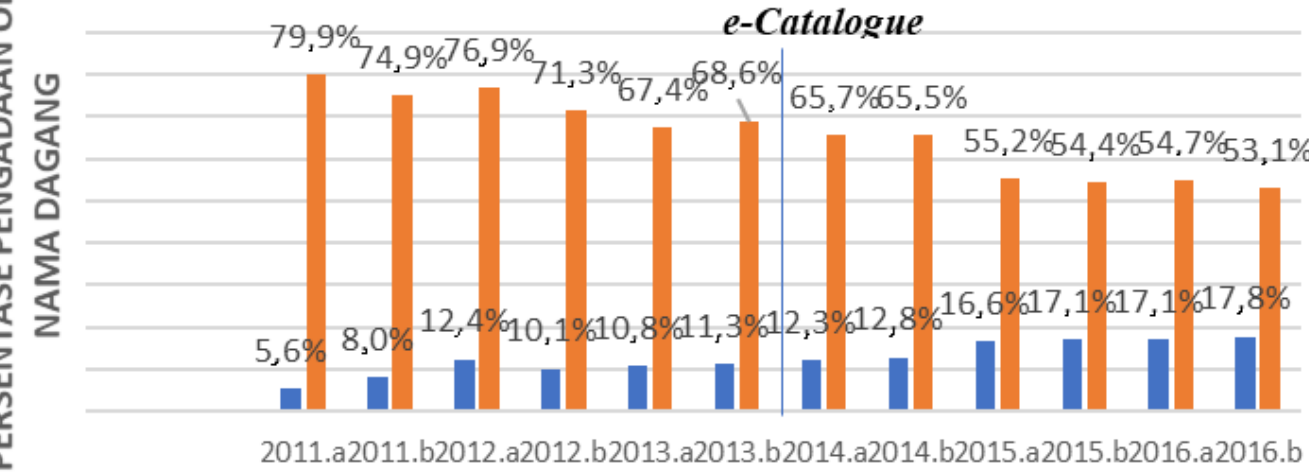

PERIODE PENGADAAN OBAT

- Persentase obat e-Catalogue a Persentase obat Non e-Catalogue

Gambar 2. Persentase pengadaan obat nama dagang e-catalogue dan non e-catalogue periode tahun 2011-2016.

Pada tahun 2013, variasi obat sangatlah lebar dan tidak terkontrol sehingga mengakibatkan pemborosan. Variasi obat perlu lebih dibatasi dan lebih dikontrol agar belanja obat menjadi relatif lebih murah. Selain itu, peresepan obat juga diyakini masih tidak rasional. Lebih dari $50 \%$ peresepan obat- obatan yang diresepkan dokter tidak tepat, tidak efektif, dan tidak efisien.

Pemerintah perlu memiliki aturan yang lebih ketat lagi terkait peresepan obat, termasuk sanksinya. Dalam praktiknya, dibutuhkan 'polisi' sebagai pihak ketiga serta 'wasit ' (Yusuf, 2013). Untuk mengatasi hal tersebut, 
sejak tahun 2014, jenis obat yang distandarisasi untuk JKN termasuk di dalam Fornas, sedang harganya ditetapkan oleh LKPP dalam e-catalogue (Kementerian Kesehatan Republik Indonesia, 2015).

Pengadaan obat nama dagang non e-catalogue setelah penerapan $e$ catalogue masih tinggi, yaitu di atas 50\% karena masih digunakannya Formularium Rumah Sakit Umum Pusat Fatmawati di samping Fornas sebagai acuan dokter untuk menuliskan resep.

Pengadaan Obat Paten e-Catalogue dan Non e-Catalogue Periode 2011-2016

Gambar 3 memperlihatkan persentase pengadaan obat paten $e$ catalogue pada periode setelah penerapan kebijakan e-catalogue tahun 2014-2016. Hasil tersebut menunjukkan kecenderungan lebih tinggi dibandingkan dengan periode sebelum penerapan kebijakan e-catalogue, yaitu pada kisaran angka 2,7-4,2\%, dibandingkan periode sebelumnya pada kisaran angka 1,8 sampai $3,6 \%$.

Persentase pengadaan obat paten non e-catalogue pada periode setelah penerapan kebijakan e-catalogue tahun 2014-2016 relatif hampir sama dengan periode sebelum penerapan kebijakan e-catalogue, yaitu pada kisaran angka 1,4-1,9\%, dibandingkan periode sebelumnya pada kisaran angka 1,1 sampai $1,9 \%$. Idealnya, persentase pengadaan obat paten non e-catalogue harus jauh lebih rendah dibandingkan dengan obat paten e-catalogue. Hal ini sesuai dengan Keputusan Menteri
Kesehatan Republik Indonesia tentang Pedoman Penyusunan dan Penerapan Formularium Nasional, yang menyebutkan bahwa tujuan utama pengaturan obat dalam Fornas adalah meningkatkan mutu pelayanan kesehatan, melalui peningkatan efektivitas dan efisiensi pengobatan sehingga tercapai penggunaan obat rasional. Bagi tenaga kesehatan, Fornas bermanfaat sebagai acuan bagi penulis resep, mengoptimalkan pelayanan kepada pasien, serta memudahkan perencanaan dan penyediaan obat di fasilitas pelayanan kesehatan (Kementerian Kesehatan Republik Indonesia, 2015). Dalam rangka meningkatkan efektifitas, efisiensi, dan transparansi dalam proses pengadaan obat program JKN, telah tersedia $e$ catalogue sebagai sistem informasi elektronik yang memuat daftar, jenis, spesifikasi teknis, dan harga barang tertentu dari berbagai penyedia barang/jasa pemerintah (Kementerian Kesehatan Republik Indonesia, 2014).

Persentase pengadaan obat paten non e-catalogue, pada kenyataanya berada pada kisaran angka yang tidak jauh berbeda baik pada periode sebelum ataupun sesudah penerapan kebijakan e-Catalogue karena pemilihan jenis obat ini ditentukan dengan mengacu pada Formularium Rumah Sakit RSUP Fatmawati yang berisi seluruh obat yang tercantum dalam Fornas dan obat lain yang diusulkan oleh Kelompok Satuan Medis (KSM). 


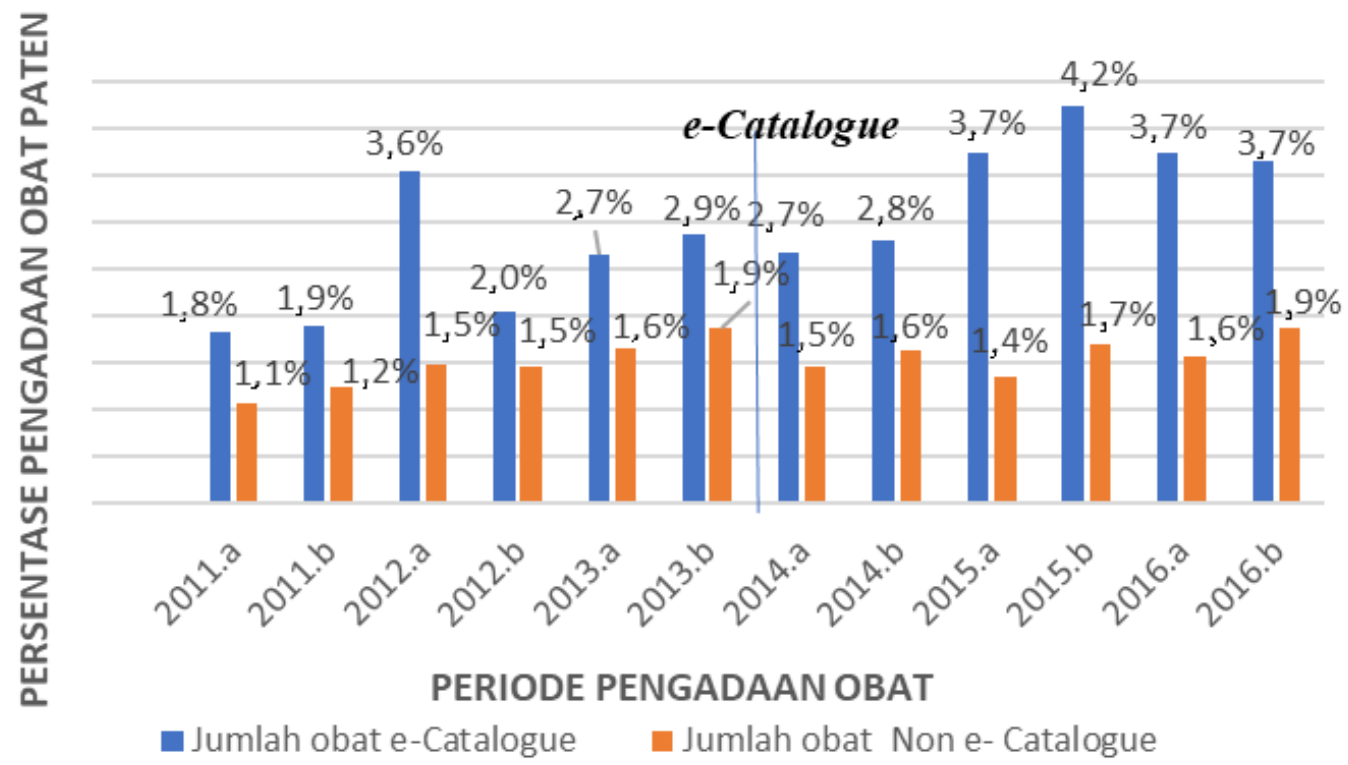

Gambar 3. Persentase pengadaan obat paten e-catalogue dan non e-catalogue periode tahun 2011-2016.

Formularium RSUP Fatmawati edisi VII tahun 2014 meliputi 960 jenis obat yang terdiri dari:

a. 578 jenis obat generik Fornas

b. 382 jenis obat non Fornas

c. 1 obat generik, 1 obat original (bila diperlukan) dan maksimal 2 obat copy (me too) sehingga terdapat 1639 nama obat (RSUP Fatmawati, 2014).

Dokter yang mempunyai pilihan terhadap obat paten tertentu harus didasarkan pada pertimbangan farmakologi dan terapi (Satibi, 2017).

\section{Simpulan}

Hasil penelitan menunjukkan bahwa penerapan kebijakan e-catalogue memberikan dampak peningkatan jumlah pengadaan obat yang masuk ke dalam daftar e-catalogue, baik obat generik, obat nama dagang maupun obat paten serta peningkatan obat generik yang tidak masuk ke dalam daftar $e$ catalogue (non e-catalogue). Penerapan kebijakan tersebut juga memberikan dampak pada penurunan pengadaan obat nama dagang yang tidak masuk ke dalam daftar e-catalogue (non $e$ catalogue) yang diterbitkan oleh LKPP.

\section{Daftar Pustaka}

Anggriani, Y., Ibrahim, M.I.M., Suryawati, S., Shafie, A.A. 2013. The impact of Indonesian generic medicine pricing policy on medicine prices. Journal of Generic Medicines: the Business Journal for the Generic Medicines Sector, 10(3-4):219229.

Ariati, N. 2017. Tata kelola obat di era sistem Jaminan Kesehatan Nasional (JKN). Jurnal Integritas, $3(2): 234-238$. 
Atikeler, E.K. dan Ozcelikayz, G. 2016. Comparison of pharmaceutical pricing and reimbursement systems in Turkey and certain EU countries. Springer Plus, 5:1876.

Darling, M. dan Wise, S. 2010. Not your father's supply chain. Materials Management in Health Care, 19 (4):30-33.

Dewi, S.L. 2014. Beberapa titik kritis kebijakan obat dalam sistem jaminan social. Jurnal Kebijakan Kesehatan Indonesia, 3(1):1-2.

Fitriani, S., Darmansyah dan Abadi, M.Y. 2014. Faktor-faktor yang mempengaruhi kepatuhan dokter dalam menuliskan resep sesuai formularium di RSUP Dr. Wahidin Sudirohusodo. http://repository.unhas.ac.id/ha ndle/123456789/14407. Data diakses pada 1 Mei 2019.

Kementerian Kesehatan Republik Indonesia. 2014. Peraturan Menteri Kesehatan Republik Indonesia Nomor 63 Tahun 2014 tentang Pengadaan Obat Berdasarkan Katalog Elektronik e-Catalogue.

Kementerian Kesehatan Republik Indonesia. 2015. Keputusan Menteri Kesehatan Republik Indonesia Nomor HK.02.02 /Menkes/524/2015 tentang Pedoman Penyusunan dan Penerapan Formularium Nasional.

Lu, Y., Hernandez, P., Abegunde, D., Edejer, T. 2011. Medicine expenditures. in The world medicines situation 2011.

Geneva: World Health

Organization.

Oktaviani, A. dan Baroroh, F. 2015. Studi pengelolaan obat sebelum dan sesudah JKN di Puskesmas Jetis Kota Yogyakarta. Pharmaciana, 5 (1):85-91.

Prabowo, P., Satibi, dan Pamudji, G. 2016. Analisis faktor-faktor yang mempengaruhi ketersediaan obat di era JKN pada rumah sakit umum daerah. Jurnal Manajemen dan Pelayanan Farmasi, 6(3):213-218.

Ruggeri, K. dan Nolte, E. 2013. Pharmaceutical pricing, the use of external reference pricing. Rand Health Quarterly, 3(2):6.

Rumah Sakit Umum Pusat Fatmawati. 2014. Formularium Obat RSUP Fatmawati. Edisi VII. Jakarta: Rumah Sakit Umum Pusat Fatmawati.

Satibi. 2017. Manajemen Obat di Rumah Sakit. Yogyakarta: Gadjah Mada University Press.

Susanto, A., Kristin, E., dan Agastya. 2017. Identifikasi faktor yang mempengaruhi total biaya inventori obat-obatan golongan A di rumah sakit swasta tipe $B$ di Jakarta tahun 2015. Jurnal Medicoeticolegal dan Manajemen Rumah Sakit, 6(1):18.

Yusuf, R. 2013. Potensi risiko fiskal program jaminan kesehatan nasional. in SJSN: Menyambut Era Baru Jaminan Social. Eds. 
Aziz, A., Setiawan, H., Mulyono, R. Jakarta: Pusat Pengelolaan Risiko Fiskal. 